\title{
The possibilities of entering new markets for Romanian companies from
}

\section{wood manufacturing industries}

\author{
Mester Liana Eugenia ${ }^{1}$, Bugnar Nicoleta Georgeta ${ }^{1}$, Mester Dinu Grigore ${ }^{2}$, Petrica Dana Maria ${ }^{3}$ \\ (1. University of Oradea, Oradea 410605, Romania; \\ 2. Parisot Green Sofa, Oradea 410605, Romania; 3. Mobila Alfa, Oradea 410605, Romania)
}

\begin{abstract}
Romania has the potential of resources, labor and real capacity to adapt to the gait of a global economic competition. But it required a long term policy and environment which could support this potential value. If not, we will risk turning into a consumer economy, consumption will not be funded on internal production and become supplier of labor services for peripheral. In the context of economic crisis, Romanian furniture retains its significant competitive advantages, including the price in export markets. The most important markets for exporters of furniture from Romania are Ukraine and Russia, markets with great potential, but affected by problems such as devaluing local currencies, and recently, imposing new duties.
\end{abstract}

Key words: wood manufacturing industry; market; supply; demand; foreign competition

\section{Introduction}

The beginning of the Romanian furniture industry is after the year 1900. Thus, in 1915, there were 12 furniture factories and 70 carpentry, and in 1944, there were 73 furniture factories and 86 carpentry.

From the 1950s, Romania began the construction of new furniture factories with equipments to the periods in question, and in 1990, were 497 factories in which there was production, mainly in the organizational structures of large enterprises. After 1990, all production units of furniture were reorganized as private companies that are still running currently.

In 2003, there were over 3,876 registered companies having, as main activity, the manufacture of furniture, of which approximately, 80 are large companies, 295 are medium companies and others are small companies. In 2009 , there were over 4,550 registered companies having, as main activity, the manufacture of furniture, of which approximately 100 are large, approximately 450 are medium and others are small. Furthermore, there are workshops with fewer than 10 employees and production units for furniture in companies of another main activity.

Romanian furniture factories were designed and built as fully integrated systems, without cooperation with other departments or factories of large enterprises. Regarding their equipment, most factories have modernized their technology in part, but did not reach the level of performance on the external market, which affect the level of labor productivity and product quality (Mester, Bugnar \& Petrica, 2009).

Mester Liana Eugenia, Ph.D., senior lecturer, University of Oradea; research field: economy.

Bugnar Nicoleta Georgeta, Ph.D., senior lecturer, University of Oradea; research field: management.

Mester Dinu Grigore, economist, Parisot Green Sofa; research field: sustainable organization development.

Petrica Dana Maria, economist, Mobila Alfa; research field: international commerce. 
Labor used in the furniture industry is made by about 90,500 people, representing $6.5 \%$ of total employment in the industry of Romania. Production of furniture made in 2008 was 1,350 million Euros, of which about $75 \%$ was exported (see Table 1 and Fig. 1). In the furniture industry in Romania, the companies are private ones. There is no monopoly in the production and selling of furniture, and export of furniture is fully liberalized. The volume of Romanian exports of furniture in 2008 was 950 million Euros, of which $77 \%$ was delivered in EU countries (mainly in Germany: 17\%, France: 18.25\%, Netherlands: $8.1 \%$, Italy: 12.5\%); Romanian exports of furniture represent $4 \%$ of total Romanian exports. In 2009, the volume of Romanian exports of furniture was 730 million Euros, of which 70\% was delivered in EU countries (mainly in Germany: 15\%, France: 16.5\%, Netherlands: 8\%, Italy: $13 \%$ ); Romanian exports of furniture represent $4.5 \%$ of total Romanian exports.

For 2010, it is estimated that the furniture export will increase, and it will reach the level of 2008 at least.

Table 1 The evolution of Romanian export of furniture (2008-2010*)

\begin{tabular}{lllll}
\hline & \multicolumn{2}{c}{ Export of furniture } & RO export for & $\begin{array}{l}\text { RO export for other } \\
(\%)\end{array}$ \\
\cline { 2 - 5 } & mil. euro & $\begin{array}{l}\text { Percent in RO } \\
\text { export (\%) }\end{array}$ & EU (\%) & 33 \\
\hline 2008 & 950 & 4 & 77 & 30 \\
2009 & 730 & 4.5 & 70 & 20 \\
$2010^{*}$ & 945 & 4.1 & 80 & 20 \\
\hline
\end{tabular}

Note: * estimate.

Data source: Romanian Furniture Producers’ Association, 2008-2010.

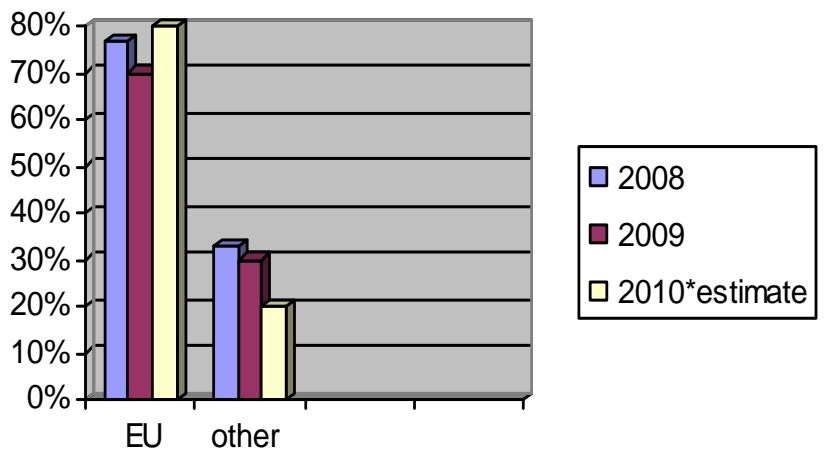

Fig. 1 The evolution of Romanian export of furniture 2008-2010

Note: * 2010 estimate.

The evolution of Romanian export of furniture in EU and in other country in the period 2008-2010 is represented in Fig. 2 and Fig. 3.

Labor productivity in the wood industry in Romania is under the average of the countries in the European Union because this sector doesn't have a complete technology, so productivity is 10,500 euro per employee in Romania in 2009 and 97,000 euro per employee in the European Union. Automation and computerization of the manufacturing sector will lead to increased productivity, then less people, but better paid.

We can also mention the need to invest in manufacturing with local and foreign capital, amounting to 20-25 billion euro in the period 2007-2013, and to amplify the exports of industrial products in an average annual rate of $15 \%-18 \%$. Another crucial factor is to build an environment fostered development of this industry, compared with that existing in developed countries of the European Union. Labor productivity growth in manufacturing sector 
with $10 \%-15 \%$ per year is one of the main objectives for the coming period to remove the gaps from the countries of the European Union (Clague \& Rausser, 1992).

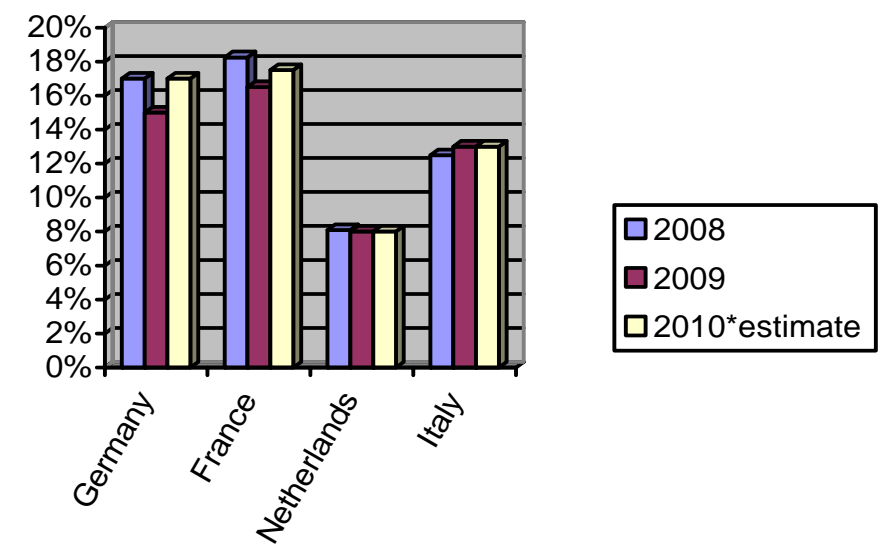

Fig. 2 The evolution of Romanian export of furniture in EU 2008-2010 Note: * 2010 estimate.

Data source: The National Institute for Statistics, Anuarul Statistic al Romaniei, 2008-2010, (3).

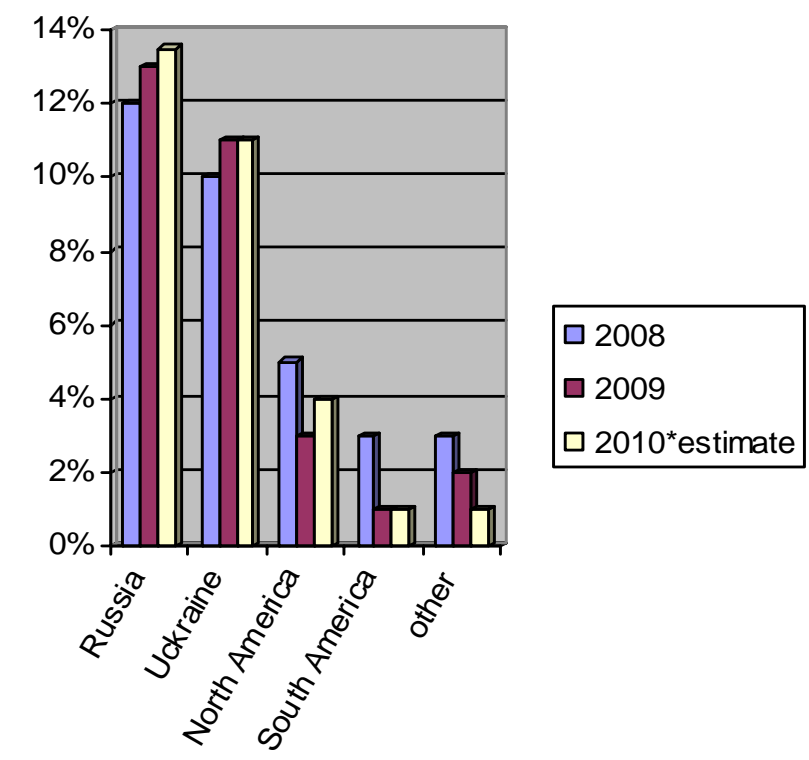

Fig. 3 The evolution of Romanian export of furniture in other country 2008-2010

Note: * 2010 estimate.

"Romania has the potential of resources, labor and real capacity to adapt to the gait of a global economic competition. But, it required a long term policy and the environment in which to put this potential value. If not, we risk turning into a consumer economy, consumption will not be funded on internal production, and to become supplier of labor services for peripheral" (Association of Business People in Romania, 2009). 


\section{Romanian companies from wood manufacturing industries}

(1) Market size and trends

The furniture sector was highly affected in the 1990s recession, and could see the effects, such as reducing the number of changes in housing, in conjunction with raising interest rates, rising unemployment and the degree of consumer debt, lack of confidence in the overall situation. Since 1995, the situation was improving, recent years became very favorable for manufacturers of furniture. For the future, it is expecting a new stagnation, because real estate prices have risen enormously, it seems that it's time to stop for the housing market.

(2) Domestic supply

Local production of wood and upholstered furniture has a traditional quality. Although a large part of domestic furniture manufacturers were forced to abandon their businesses and close the factories, however, competition is strong, those who resisted the market managed to grow enough to complete each other. The authors offer an example: The most powerful of furniture producers from Romania has over 7 different production plants, each specialized on certain classes of products helping them to provide more products of exceptional quality, and at the same time, benefiting from an increased efficiency production by specializing each factory only on two or three distinct models. However, Mobila Alfa is one of the first 10 furniture manufacturers in Romania.

(3) Foreign competition

Most European countries are present on the Russian market, particularly because high absorption capacity of this market. Starting from Italy, the main exporter, followed by Poland, Romania and then, less and the other countries represented. Their products are mainly designed for a demanding market and are looking for their innovative character: design, materials and colors. Italian products are popular for design and flexible application. Asia and Eastern Europe meet customer oriented products at the bottom of the range.

(4) Demand-Consumer profile

Due to proximity to achieve saturation of almost all market segments, there is observed a sustained increase in the sales of furniture, but rather a horizontal line without extraordinary growth.

Housing in these areas are generally very spacious, so it observed preference of those customers for massive furniture, classic in terms of the model, the dark finish, and with different trim models, sculpture, paint, even precious stones and crystals. A market study been done in 2000 shows that the age sectors less likely to purchase furniture are under 25 years and over 64 years. These consumers have limited disposable income and are less interested in installing a home or interior refurbishment.

Sectors of intermediate age are potential buyers. One can notice a decrease in purchasing regular buyers of 50 years past. They are very sought after by companies, because they are willing to pay more for quality products.

In socioeconomic terms, it is not surprising that a class with high purchasing power is most familiar to buy. Following the same logic, those with less money buy less. Population age will certainly impact on future demand: This sector is in the age group of consumers with high purchasing power, more demanding and selective. Aesthetics with ergonomics are important purchase criteria.

Russian consumers give great importance to quality-price ratio and product image when it acquires. Comfort is also considered, especially in terms of upholstered furniture and design is crucial for buyers of wood furniture. Less than one third of buyers give quick deliveries or immediate importance (see Table 2). 
Table 2 Factors influencing the purchase of furniture

\begin{tabular}{ll}
\hline Factors & Percentage $(\%)^{\mathrm{a}}$ \\
\hline Ratio quality/Price & 57 \\
Image & 52 \\
Color & 39 \\
Sustainability & 37 \\
Guarantee & 29 \\
Design & 47 \\
High quality & 28 \\
Comfort & 25 \\
Materials & 21 \\
Immediate or quick delivery & 32 \\
Qualified vendors & 15 \\
Lower prices & 21 \\
Special offers & 15 \\
Maintenance information & 7 \\
\hline
\end{tabular}

Note: ${ }^{a}$ percentage of customers indicating that factor as very important.

(5) Ecological factors

Increasingly growth of consumer's responsibility on the environment has consequences for the furniture industry. Increasingly, more manufacturers only use local essences instead of the exotic. Beech and lime are among the most sought. Due to changes that have occurred recently on the environment, sustainable development has become a necessity that requires more and more attention.

Sustainable development means maintaining a material possibilities and conditions life for future generations, particularly renewable natural resources, at least, at existing levels for the current generation. The spiritual, sustainable development means much more, is the conservation of cultural heritage material, made by the past and today the creation and development capacity in the future, the elite who we are.

Defined by CMED, sustainable development implies that the total capital consists of physical capital (machines, roads, hotels, etc.), human capital (health people, their knowledge and skills) and natural capital (forests, air, water and fertile soil) remain constant or increase over time.

Concern for growth, by any means and at any price, which took place in the last century, has led to neglect of environmental effects of this growth, which, paradoxically, resulted in a degradation of natural factors (water, air, soil, etc.) and thus a deterioration of living conditions on earth.

In Romania, one of the first "official" definitions for the environment is given in 1973 by Law No. 9 (Environmental Law) which is passed in Romania only one year after ONU Conference on Environment held in Stockholm. In this law, the environment is defined as "all natural factors (water, air, soil, subsoil, forests, land and other aquatic vegetation, reserves and monuments) and of those created by human activities (settlements) in close interaction, influencing the ecological balance and causing living conditions for human development of society" (Law No. 9/1973).

These conditions of environmental protection are also important for the timber industry, in addition to rules that must be met by producers in that industry, providing standards required by law. Special incentives are granted 
for those who want to acquire advanced technology for environmental protection (Ionescu \& Toma, 2001).

Strategic alliances are agreements between firms in which each commits resources to achieve a common set of objectives. Companies may form strategic alliances with a wide variety of players: customers, suppliers, competitors, universities or divisions of government. Through strategic alliances, companies can enhance the competitive positioning, be eligible for entry into new markets and share major risks or costs of development projects (Mester, Bugnar \& Petrica, 2009).

International strategic alliances materialize in cooperation agreements between companies, sometimes competing companies, for the exchange or sharing of activities or economic areas. These alliances, known as alliances or global strategic partnerships, means business arrangements whereby two or more partners cooperate in mutual benefit, which is designed specifically to support and strengthen the competitive advantages of partners (Danciu, 2001).

The purpose of alliances is to minimize risk while maximizing profits. Alliances can be formed in the department of marketing, sales and distribution in common, joint production, design collaboration, technology licensing and research and development. Relationships can be vertical-between a seller and a customer, horizontal - between suppliers, local or global. For small businesses, strategic alliances are a way to work with others toward a common goal while not losing their individuality. Alliances are a way to collect rewards of team effort. Alliances are often confused with mergers, acquisitions and outsourcing (Krugman \& Obstfeld, 2003). Although there are similarities in the conditions under which a business may consider these solutions, they are far from being the same. Mergers and acquisitions determine permanent changes in the structural mode in which the company exists. Outsourcing is simply a way to acquire a functional company. An alliance is a business-to-business collaboration. Another term that is commonly used in conjunction with the alliance is establishing a business network.

Rosabeth Moss Kanter, a professor at Harvard University, having an experience of over 20 years in various companies participating in strategic alliances and partnerships, compares these alliances with different couples' marriages. Such alliances are seen as equivalent of corporate "friends with benefits" (Harvard Business Review on Strategic Alliances by Harvard Business School Press, 2003).

The technology and implicit know-how is spreading faster than ever and production processes involving a particular technology is copied through benchmarking; under these conditions the companies have access to existing technology on the market in question simply by their presence here.

Because of the risk of loss of control over the know-how, we can ask what alternative forms of organization - the license, its subsidiaries, mergers - has proved to be insufficient. Reasons given by companies were: the size of investments required, the time needed by the company to make its presence felt on the market and less exposure to risk (Hamel, Yves \& Prahalad, 1989).

\section{The Romanian companies from the wood industry: SC Mobila Alfa SA-Case study}

In order to present the export development that can be expected by the Romanian companies from the wood industry, the authors chose to take an example.

SC Mobila Alfa SA is a company in Oradea, Romania, which manufactures and sells furniture on full wood 
structure. The company has been operational for over 45 years. The company enjoys a great tradition on the Romanian market, year after year ranging between the first 3 companies in wood industry from Romania. Production was done in several locations in the county which were subordinate to the headquarters of Oradea. Total number of employees exceeded 5,000 people. Currently, the company was restructured, its activity is much narrower, becoming a private company. The currently employees' number is now only around 150 people and activity takes place in a small area of the old factory location from Oradea.

The work is divided into several sectors which have a constant communication so as to ensure smooth production cycle. Starting from the needs of raw materials and production departments, purchasing department sends orders to suppliers and ensure timely receipt of goods ordered. Basic raw materials, namely timber, requiring a period of up to 60 days for drying in specially equipped rooms that must be continually monitored to ensure meeting the conditions of humidity and temperatures required for each type of timber: linden, beech, oak, etc. Dried timber pass into massive department for the purpose of cutting, then passed successively through the other sections until control is made by the quality department, and it is stored in good conditions for delivery to customers.

Design activity is a special department which includes specially trained engineers in the timber industry to create new models that are suitable for the technology and materials used. Distribution is made by Selling Department which has subordinated his own store and other stores in the country; distribution is also made by exports, both directly and indirectly. Prices are at a competitive level with other companies from this area.

At the company's beginnings, products' line consists of products created specifically for the Romanian market. Then, they started to adapt and even creating new products specifically for German market. Lately, they started to adapt products to Russian market. In the last 5 years, the company worked almost exclusively for bedroom and living room furniture adapted to this market. Only small furniture line works for the Western European market. Since last year, the production is slowly switching to the domestic market.

All products meet the necessary steps to ensure high quality output file. All furniture has certified warranty ensuring that the eventually alterations will be immediately remediated.

The latest model developed consists of a bedroom "Sevilla". From the outset, this model has aroused the interest of domestic clients, especially those in Bucharest. The product was first presented at the fair BIFE TIMB Bucharest 2009. The main characteristics of this model are straight lines, lighter than other classes and smaller, adaptable for apartments and smaller spaces, and also the prices of the bedroom are considerably lower than others. When the product was presented on the Russian market, at the International Mobile Fair in Moscow, some modifications were required on the model and in particular about color; They prefer dark color, like with other classes. So we proceeded to finish the change as requested. It remains to be seen whether these changes will be approved also by the domestic clients.

There are other models that the authors are currently working on.

Two possibilities have been identified as a means of sustainable growth: adding new models to the production line and entering new markets.

Since products are specially designed for Eastern market, the company is looking for expanding markets of Russia and Ukraine. These markets have several characteristics to distinguish them from other, but they are highly sought by Romanian producers with a high purchasing capacity.

(1) Question 1: How should SC Mobila Alfa SA proceed in order to enlarge export market of Russia, given 
that it is a relatively small company operating in the field?

Answer: From the real situation of company, namely the fact that all sales activity, both internally and externally, is done by the same department, which consists only of two personae, the best option that one could consider is the indirect export. By concluding, contracts with intermediaries and export turnover could increase and would benefit from their advantages, mainly due to an experience that these intermediaries have on those markets. These intermediaries know the form of advertising with the greatest effect on those markets, know the chain stores with the biggest sales of furniture, and have storage facilities so that they can carry large quantities of products to reduce transport costs. These are advantages that must not be ignored, even if the prices obtained for products sold by intermediaries are lower than they could be obtained by delivering directly to stores in those areas. At the conclusion, we can say that the contracts with these intermediaries must take account of some mandatory elements:

(a) Fundamental provisions:

- name of exporter and representative;

- line of products covered by the agreement;

- the territory assigned must be clearly defined;

- must specify clearly whether or not the agreement is mutually exclusive in the sale of the territory assigned;

- prices for customers (agent) should be maintained as it was stipulated;

- provision for payment for samples and samples rebate.

(b) Terms of sale:

- the terms of sale are stipulated and must specify whether the offer is made as buyer's representative for its own account or as a salesman on a commission basis;

- should include payment terms;

- must specify the nature and rate of compensation and when and how the payment will be made;

- the exporter shall retain the right to refuse any customer orders that are not in accordance with the exporter or quotations are not approved for credit, or impossible to fulfill for reasons beyond the control of the exporter.

(c) General provisions:

- show how and when the agreement enters into force. Agreement is interpreted under the laws of the country where it is consumed;

- if consent to enter into force after receiving the first order must be observed during the in force and stipulates that between the time the exporter shall make no other representation of products listed offer another representative in the territory;

- how to resolve disputes;

- indicate complete agreement. This is generally a measure of cancellation after a certain time period after notification, to be satisfied all the obligations stipulated.

(2) Questions 2: What other issues should be considered to ensure the smooth running of the business of selling products on other markets than domestic?

Answer: If we consider the "marketing activity", it is necessary that the company's management team includes in annual revenue budget about $3 \%-4 \%$ of turnover, devoted to promoting and advertising creative. When it comes to promote, the intermediary must receive certain discounts that can be given for large quantities of 
products purchased and also incentives and discounts for the purchase and promotion of new products. And, as regards domestic marketing deliveries, one must allocate funds for both regular advertisements in print media and through the others, television, radio, magazines and also participation at fairs and exhibitions in the field.

\section{Conclusion}

Although we presented briefly the actual situation of Mobila Alfa, one can observe the complexity of business and the problems which one must face in order to ensure the possible development of activity. This brings the need for a dedicated and willing personal development to assimilate all the information provided by the changes constantly occurring in the economic environment.

\section{References:}

Clague, C. \& Rausser, G. C.. (1992). The emergence of market economies in Eastern Europe. Cambridge, Massachusetts, USA: Blackwell Publishers, 76-79.

Danciu, V.. (2001). International marketing: From traditional to global. Bucharest: Economic Press, 244.

Hamel, G., Yves, D. \& Prahalad, C. K.. (1989). Collaborate with your competitors and win. Harvard Business Review, 139.

Harvard business review on strategic alliances. (2003). Boston: Harvard Business School Press, 124.

Informational Journal of Romanian Furniture Producers' Association. (2009). Year XV, no. 168 / no.3/2009.

Informational Journal of Romanian Furniture Producers' Association. (2009). Year XV, no. 168 / no.5/2009.

Informational Journal of Romanian Furniture Producers' Association. (2009). Year XV, no. 168 / no.6/2009.

Ionescu, G. \& Toma, A.. (2001). Cultura organizațională şi managementul tranziţiei. Bucureşti: Editura Economică, 89-96.

Johansson, J.. (1985). International alliances: Why now? Journal of the Academy of Marketing Science, Fall, 56.

Krugman, P. R. \& Obstfeld, M.. (2003). International economics: Theory and policy. Boston: Addison Wesley Longman.

Mester, L., Bugnar, N., Bodog, S. \& Petrica, D.. (2009). The competitive advantages of the Romanian manufacturing industry. In: International Conference Proceedings, Sousse, Tunisia.

Mester, L., Bugnar, N. \& Petrica, D.. (2009). Strategic alliances: From success to failure. University of Oradea, Oradea.

Steinhilber, S.. (2008). Strategic alliances: Three ways to make them work. Boston: Harvard Business School Press, 28.

Stephen I. G. \& Craig, M. W.. (2003). Partnerships, joint ventures \& strategic alliances. Boston: Harvard Business School Press, 1127.

The National Institute for Statistics. (2000-2009). Anuarul statistic al Romaniei.

(Edited by Ruby and Chris) 